\title{
KEARIFAN LOKAL MASYARAKAT DESA GAMBUT DI PROVINSI RIAU
}

\section{LOCAL WISDOM OF GAMBUT VILLAGE SOCIETY IN RIAU PROVINCE}

\author{
M. Rawa El Amady \\ Perkumpulan Scale Up \\ Komplek Villa Garuda Mas Blok A 03 \\ Jalan Garuda Sakti RT 03 RW 08 Kelurahan Labuhbaru Timur \\ Kecamatan Payung Sekaki Pekanbaru Riau 28292 \\ e-mail : mrawaelamady@gmal.com \\ DOI: $10.36424 / j p s b . v 6 i 2.181$ \\ Naskah Diterima: 06 Juni 2020 Naskah Direvisi: 05 Oktober 2020 \\ Naskah Disetujui: 05 Oktober 2020
}

\begin{abstract}
Abstrak
Kajian ini membahas tentang kearifan lokal pada budi daya pertanian di lima desa gambut di Riau. Di Indonesia terdapat 10,8\% kawasan gambut dari luas daratan di Indonesia. Masyarakat sudah hidup di kawasan gambut sejak abad ke 3 masehi dan desa gambut di Riau sudah ada sejak abas ke 19. Dapat dipastikan bahwa kearifan lokal sudah menjadi tatanan nilai di masyarakat di kawasan gambut Indonesia, termasuk di Riau. Kajian ini merupakan kajian kualitatif dengan mengacu pada penelitian rapid etnografi, data diperoleh dengan observasi cepat, wawancara mendalam, diskusi grup terfokus dan studi perspustakaan. Informan diperoleh dari kepala desa dan tokoh masyarakat melalaui snow ball. Penelitian dilakukan di lima desa gambut di Kabupaten Pelalawan, Kabupaten Siak, Kabupaten Kepulauan Meranti dan Kabupaten Indragiri Hilir. Data dianalisis secara diskriptif menggunakan pendekatan konstruktif melalui tahapan dan kecenderungan pola data dan berdiskusi pada teori. Kajian ini melaporkan bahwa kearifan lokal di lima desa gambut berasal dari tanah mineral hulu sungai dan budaya maritim tanah aluvial, yang kemudian membentuk kearifan lokal di desa-desa tersebut; Masyarakat tidak mengelola gambut dalam atau hanya mengelola gambut dengan kedalaman satu meter; Mata pencaharian masyarakat berbasis pencarahairan jangka panjang dan harian dengan beragam kegiatan dan komuditas misalnya sagu, kelapa, nanas, melon dan cabe, Pengelolaan kesuburan berbasis pada jenis komuditas, dan kanal dangkal; serta terdapat institusi ekonomi toke sebagai pembeli hasil pertanian masyarakat dan penyedia hutang.
\end{abstract}

Kata Kunci : Kearifan lokal, usaha pertanian, budaya pertanian dan gambut. 


\begin{abstract}
This study discusses local wisdom in agricultural cultivation in five Gambut Villages in Riau. In Indonesia, there are $10.8 \%$ of the peat area of the total land area in Indonesia. The community has lived in the peat area since the 3rd century AD. Gambut Village in Riau has existed since the 19th century. It is the fact that local wisdom is very essential value in the peat area in Indonesia including the one in Riau. It is a qualitative study with a rapid ethnographic design. Data are collected through quick observation, in-depth interviews, focus group discussions and library studies. Informants were selected by village head and informal leader through snowball technique. The research was conducted in five Gambut Village in Palalawan District, Siak District, Kepulauan Meranti District, and Indragiri Hilir District. The data were analyzed descriptively by applying constructive approach. The analysis was also done by observing the tendency of data pattern and by referring to the theory. The results of the research indicate that local wisdom in five Gambut Village originated from mineral land of river upstream and maritime culture of alluvial land, which later formed local wisdom in those five villages. The community does not cultivate peat area at depth but only one meter. The income of the society is in the form of long term basis and daily with various commodities such as sago, coconut, pineapple, melon and chilies. Fertility management is based on commodity types and shallow canals. Then, there is the economy institution named Toke as the buyer of the commodities and at the same time as the debt provider.
\end{abstract}

.Keywords: Local wisdom, agricultural cultivation, agricultural and peatland culture.

\title{
PENDAHULUAN
}

Kajian ini merupakan upaya memotret kearifan lokal di desa gambut, khususnya di Riau. Sebagaimana diketahui bahwa gambut di Indonesia merupakan bagian yang tidak terpisahkan dari masyarakat Indonesia. Indonesia memiliki 20,0 juta hektar lahan gambut atau sekitar 10,8\% dari luas daratan di Indonesia. Sebaran gambut terdapat, tersebar $41 \%$ di Sumatera, 23,1\% di Papua, 22,8\% di Kalimantan, 1,6\% di Sulauwesi dan 0,5\% di Halma Hera. (Amady, 2015).

Masyarakatpun sudah hidup di ekosistem gambut sejak abad ke 3 Masehi, hingga tahun 1970-an ekosistem gambut terjaga dengan baik dan berkelanjutan, (Utomo, 2015: 128-129). Hal ini juga diperkuat oleh Noor (2007: 5) yang mengemukakan bahwa pengembangan kawasan gambut sudah 
dimulai sejak abad ke 13 Masehi saat Kerajaan Majapahit memperluas pengaruhnya di Kalimantan. Vita (2016: 2) juga melaporkan bahwa masyarakat pra-sriwijaya yang hidup di lahan basah (gambut) di Situs Air Sugihan yang berada di sumatera timur berdekatan dengan Semenanjung Kampar mengubah ekosistem gambut menjadi tempat tinggal, memenuhi kebutuhan hidupnya dan beradaptasi pada perubahan ekosistem gambut tersebut.

Ekosistem gambut yang terdiri dari ekosistem biotik dan abiotik sudah dipastikan memberi corak bagi ekosistem sosial ekonomi masyarakat yang hidup di atasnya. Relasi sosial dan budaya yang tumbuh dan berkembang sudah dipastikan berbasis gambut, seperti budaya produksi, budaya konsumsi, arsitektur, teknologi, transportasi, tata kelola air, hubungan manusia dengan alam dan lain-lainnya. Relasi sosial dan budaya ${ }^{1}$ tersebut terbangun sejak awal terbentuknya desa, dan selalu beradaptasi terhadap perubahan ekosistem.

Catatan-catatan berdirinya desa-desa di ekositem gambut Riau sudah mulai ada sejak tahun 1830-an dan 1940-an. Perpindahan penduduk dari kawasasan lain $^{2}$ ke desa-desa ekosistem gambut disebabkan oleh faktor pemanfaatan tumbuhan yang hidup di ekosistem gambut seperti sagu, kelapa, pinang dan karet sebagai sumber penghidupan utama. Selama puluhan tahun masyarakat hidup di ekosistem gambut sudah dipastikan masyarakat mempunyai pengetahuan dan teknologi untuk hidup di ekosistem gambut, sehingga gambut tetap terjaga. Masyarakat sudah dipastikan mempunyai teknologi pertanian mulai dari memilih tempat, memilih bibit dan tanaman yang tepat, persiapan tanam, teknologi penanaman pemeliharaan, panen dan pasca panen.

\footnotetext{
${ }^{1}$ Budaya dalam defenisi ini bukan hanya kegiatan berkesenian saja, tetapi sebuah tatanan nilai hidup bersama dalam masyarakat.

${ }^{2}$ Dalam hal ini dari hulu Sungai Kampar dan hulu Sungai Siak, Sungai Musi, Kepulauan Riau, dan Jawa
} 
Manusia dan lingkungan membentuk ekosistem yang berinteraksi untuk suatu kesatuan keteraturan. Manusia membangun ekosistem sosial ekonomi yang berbasis pada ekosistem biotik dan abiotik. Ekosistem biotik dan abiotik membentuk ekosistem sosial ekonomi yang diaktualisasikan melalui pranata sosial dan budaya. Masyarakat yang hidup di ekosistem gambut secara sadar yang berbasis pada pengetahuannya membentuk ekosistem sosial ekonomi yang berbasis gambut dengan mudah dapat dikenali melalui prilaku sosial ekonomi masyarakat, seperti budaya produksi, budaya konsumsi, arsitektur, teknologi, transportasi, tata kelola air, hubungan manusia dengan alam dan lain-lainnya. Ekosistem sosial ekonomi ini selalu beradaptasi terhadap ekosistem biotik dan abiotik gambut. Berdasarkan uraian-uraian di atas, peneliian ini memoren kearifan lokal pada budidaya peranian didesa gambu. Peranyaan diajukan pada penelitian ini adalah apakah kearifan lokal pada budi daya peranian di desa-desa peneliian?

Riset ini membangun hipotesis bahwa pada setiap komunitas dipastikan memiliki kearifan dan pengetahuan lokal. Kearifan dan pengetahuan lokal merupakan hasil interaksi antara manusia dengan alam untuk bertahan hidup. Manusia dan lingkungan membentuk ekosistem yang berinteraksi untuk suatu kesatuan keteraturan. Manusia merupakan variabel terikat pada lingkungannya yang bertidak sebagai variabel bebas, oleh sebab itu manusia bertahan hidup dengan tata cara yang dipengaruhi oleh lingkungannya.

Untuk bertahan hidup, sebagaimana disampaikan Prasetijo (2008) bahwa individu dan masyarakat bekerja secara aktif untuk menghadapi kondisi lingkungan tertentu dengan memodifikasi prilaku mereka untuk memelihara kondisi tertentu, menanggulangi resiko tertentu pada kondisi yang baru atau mengimprovisasi kondisi yang sudah ada. Menurut saya, bukan hanya itu, individu dan masyarakat tetap menjalani prilaku yang sudah ada pada kondisi yang baru, sebagaimana dilaporkan Seger (2019: 13-14) bahwa di Desa Lukun Tebing Tinggi Barat Kepaulauan Meranti masyarakat masih menggunakan kearifan lokal dalam aktivitas bertani. Cara-cara 
tradisional masih mereka lakukan dengan berbagai macam ketentuan nilainilai leluhur yang ada di dalam warisan budaya tersebut sangat bermanfaat untuk menjaga kelestarian gambut.

Menurut Prayitno (2013:53-58), masyarakat memproduksi nilai-nilai kearifan lokal untuk mengerem percepatan perubahan melalui mitos, ritual, dan pitutur luhur yang erat kaitannya dengan alam. Nilai-nilai kearifan lokal tersebut mampu mengatur masyarakat sedemikian rupa dalam hubungannya dengan lingkungan sekitar. Kearifan lokal sudah mengantisipasi kerusakan lingkungan/ekosistem sehingga kearifan lokal justru lebih dahulu berperan dalam menjaga kelestarian lingkungan, sehingga keberadaan kearifan lokal sama umurnya dengan keberadaan manusia di lingkungan dia berada (Amady, 2015: 18-21). Kearifan lokal lebih berperan dalam menjaga ekosistem dari pada hukum formal.

\section{METODE PENELITIAN}

Riset ini merupakan riset kualitatif dengan menggunakan desain penelitian yang mengacu pada rapid etnografi (etnografi cepat). Rapid etnografi adalah penelitian mengacu pada etnografi dengan waktu yang terbatas, melibatkan tim riset dari berbagai disiplin ilmu dengan menggunakan observasi singkat, wawancara mendalam dan grup diskusi terfokus. Sebagaimana riset etnografi penelitian ini melakukan penafsiran budaya dan sistem kelompok sosial, mendalami aspek historis, interaksi sosial budaya dan praktek kehidupan sehari-hari masyarakat.

Untuk memastikan kedalaman informasi maka penelitian ini dilakukan dua tahap, pertama melakukan studi perpustakaan berbasis internet untuk mendapat data sekunder berupa hasil penelitian dan laporan masyarakat. Hasil studi internet ini, lalu dituliskan sebagai draf awal untuk menjadi pengetahuan dan petunjuk mengenali data lebih dalam. Tahap kedua, tim peneliti yang terdiri dari disiplin antropologi, ilmu politik dan sosial ekonomi perikanan turun ke lima desa untuk melakukan diskusi terfokus, wawancara 
mendalam, observasi desa dan kegiatan pertanian, serta aktivitas sosial ekonoi lainnya.

Penelitian dilakukan di lima desa gambut, yaiu di Desa Pulau Muda di Kecamatan Teluk Meranti Kabupaten Pelalawan, Desa Dayun Kecamatan Dayun dan Desa Lalang Kecamatan Sungai Apit di Kabupaten Siak, Desa Tanjung Kecamatan Tebing Inggi Timur di Kabupaten Kepulauan Meranti dan Desa Pulau Burung Kecamatan Pulau Burung di Kabupaten Indragiri Hilir. Penelitian dilaksanakan sejak awal Februari 2020 sampai akhir Maret 2020 .

Secara khusus data yang diambil adalah sejarah desa, sejarah pengelolaan gambut, teknologi pertanian di kawasan gambut, budaya pertanian di kawasan gambut yang merupakan gambaran sebagai kearifan lokal masyarakat di desa gambut. Untuk mendapatkan nara sumber atau informan tim peneliti mengidentifikasi narasumber yang menjadi sumber informasi, yaitu kepala desa atau sekretaris desa, tokoh masyarakat desa yang mengetahui sejarah desa dan pengelolaan pertanian di kawasan gambut sejak awal berdiri desa, petani dan nelayan yang mengelola kawasan gambut. Untuk mendapatkan nara sumber atau informan tersebut tim peneliti langsung menuju ke kantor desa atau ke kepala desa untuk meminta izin penelitian dan sekaligus wawancara kepala desa atau sekretaris desa dan meminta informasi tokoh masyarakat, petani dan nelayan yang menjadi informan atau nara sumber. Selain sumber dari kepala desa, informasi juga diperoleh melalui informan yang diwawancarai secara mendalam.

Teknik pengambilan data dilapangan dilakukan dengan tahap berikut, pertama melakukan observasi ke seluruh wilayah desa, khususnya di kawasan gambut yang kelola untuk pertanian. Kemudian dibuat fieldnotenya agar semua tim membaca untuk memperdalam informasi. Kedua, wawancara mendalam ke informasi yang diperoleh melalu snow ball kepada seluruh infoman yang memenuhi syarat. Wawancara dilakukan secara tim direkam dengan alat perekam digital, dan dividiokan juga dengan celuler. Selesain wawancara ditranskrip dan untuk dibaca oleh tim, juga dibuat fieldnote 
wawancara. Tahap ketiga, dilakukan dikusi grup terfokus yang peserta adalah semua informan yang diwawancara dan tokoh masyarakat lainnya yang dipandang memahami dan mengerti kebutuhan informasi yang dibutuhkan. Hasil diskusi grup terfokus dibuat transkrip dan juga fieldnote. Diskusi grup terfokus ini selain untuk mendalami informasi yang sudah ada juga sebagai mekanisme verivikasi data untuk validasi data.

Proses validasi data dimulai dari data yang diperoleh dari studi perpusatakaan di internet beberapa data yang tampil dibandingkan dengan sumber informasi dan kesamaan atau perbedaan. Data yang paling banyak ditemui dari berbagai sumber data dengan rank waktu tiga tahun terakhir data tersebutlah yang dipilih untuk menjadi sumber data awal. Data awal tersebut diverikasi melalui data yang tersedia di kantor desa, divalidasi lagi melalui observasi, divalidasi lagi melalui wawancara dan divalidasi lagi melalui diskusi grup terfokus. Data yang dipakai pada laporan ini adalah data yang lolos melawati tahapan validasi tersebut.

Data yang diperoleh dari penelitian tersebut dianalisis secara diskriptif dengan mendiskusikan data pada teori. Langkah analisis dilakukan pertama, penyusunan data secara sistematis dan hasil transkrip dan fieldnote (catatan lapangan), lalu data diorganisir berdasarkan kecenderungan dan pola-pola antar unit, kemudian dikonstruksi dengan berdiskusi pada teori kemudian didiskripsikan pada laporan penelitian.

\section{PEMBAHASAN}

\section{Potret Desa Penelitian}

Penelitian dilakukan di lima desa yang ditetapkan oleh Badan Restorasi Gambut (BRG) sebagai desa gambut. Lima desa tersebut merupakan desa-desa yang berada di kawasan Semenanjung Kampar, yaitu Desa Pulau Muda Kecamatan Teluk Meranti di Kabupaten Pelalawan yang berada di pesisir Sungai Kampar, Desa Dayun Kecamatan Dayun Kabupaten Siak yang berada pesisir sungai Siak, Desa Lalang di Kecamatan Sungai Apit di pesisir Selat Malaka, Desa Tanjung di Kecamatan Tebing Tinggi Barat 
Kabupaten Kepulauan Meranti dan Desa Pulau Burung di Kecamatan Pulau Burung Kabupaten Indragiti Hilir.

Masyarakat di lima desa yang diteliti secara umum memiliki kesamaan yaitu semuanya desa gambut, secara ekonomi masih subsisten dengan basis ekonomi pada pertanian padi, karet, kelapa, pinang, nenas dan sawit. Desa Tanjung dan Desa Pulau Burung tidak terdapat tanaman sawit. Sementara desa Dayun dan Pulau Burung merupakan desa dengan basis industri.Di Desa Dayun industri andalannya adalah HTI (Hutan Tanaman Industri), perkebunan sawit dan minyak, sedangkan di Pulau Burung industri andalannya adalah perkebunan kelapa, perkebunan nanas dan pabrik pengolahan kelapa dan pupuk organik.

Di semua desa dijumpai mayoritas asal usul masyarakatnya berasal dari hulu Sungai Kampar yang berbasis budaya matrilineal dan tanah mineral. Sistem kepemilikan lahan berada di suku pendiri desa yang mempunyai hak kepemilikan diwariskan ke perempuan yang di kenal tanah ulayat. Meskipun sudah mengalami perubahan dan penyesuaian dengan budaya pesisir. Terdapat juga suku asli Akit dengan sumber penghidupan sebagai nelayan dan pengolahan hutan bakau. Basis budaya Melayu pesisir yang parental dan kepemilikan perorangan, juga dikenal dengan wilayah kawasan desa, batas desa dan kawasan kelola desa sebagai tempat aktivitas ekonomi masyarakat. Namun terdapat juga kawasan yang peruntukan untuk pegawai kerajaan yang berada di setiap desa, dengan kluster budaya yang berbeda, kawasan tanahnya sangat terbatas yang dikuasai secara individu. Mayoritas penduduk menggantungkan kehidupan kepada sungai karena sungai merupakan salah satu sumber mata pencaharian (sebagai nelayan), sumber air, MCK (mandi cuci kakus) maupun sebagai sarana transportasi.

\section{Desa Pulau Muda}

Desa Pulau Muda merupakan salah satu desa di Kecamatan Teluk Meranti Kabupaten Pelalawan sebelum tahun 1970 berada di Pulau Muda di tengah Sungai Kampar dihadapan Desa Pulau Muda sekarang. Pada tahun 
1970-an masyarakat di pulau tersebut mengalami banjir terus menerus dan penyakit cholera sehingga secara bertahap pindah ke daratan Pulau Sumatera bersebarangan dengan Pulau Muda yaitu Teluk Air yang menjadi Desa Pulau Muda sekarang. Di Pulau Muda masyarakat bertani padi, setelah pindah ke Teluk Air masyarakat bertanam kelapa, pinang, karet dan jagung. Kebijakan politik nasional yang pengarustamaan politik global menyebabkan masyarakat kehilangan kegiatan ekonomi utama yaitu berkebun jagung karena larangan membakar. Begitu juga tanaman padi di tiga tahun terakhir tidak dijumpai lagi petani padi Pulau Muda.

Pada saat ini munculnya sumber daya ekonomi baru yaitu sarang walet, terdapat lebih kurang 600 buah rumah walet yang berarti sepertiga warganya memilki walet dari 1.964 rumah tangga (KK) dengan 6.483 jiwa penduduknya. Rumah walet ini memunculkan usaha ekonomi baru sebagai ekosistem rumah walet yaitu nanas. Berkebun nanas menjadi pilihan baru kegiatan ekonomi untuk memenuhi permintaan pemilik rumah walet sebagai makanan burung walet tersebut. Amir petani nanas menyampaikan bahwa dia telah membuka dengan cara tanpa bakar dan telah menanam 7000 nanas dari 50.000 batang nanas yang direncankan. Dia bekerja sama dengan perusahaan HTI (Hutan Tanaman Industri) melakukan land clearing, semua kayu di atas tanah diambil perusahaan, lahan bisa langsung ditanam nenas.

\section{Desa Tanjung}

Desa Tanjung merupakan desa yang terbentuk karena pengembangan perkebunan sagu dari Desa Alai. Masyarakat Desa Alai menanam pohon sagu di tanah aluvial di pinggir Sungai Suir Kiri dan beberapa anak sungai Sungai Lalang, Sui Menako, Sui Kulu. Pohon sagu yang ditanam dan dibiarkan begitu saja tanpa pemeliharaan namun diketahui siapa yang menanam sagu tersebut. Setelah sagu tersebut layak panen masyarakat mulai berdiam di situ hanya untuk aktivitas panen. Setelah kebun sagu meluas, masyarakat membutuhkan waktu berhari-hari untuk memanen sagu sehingga masyarakat memutuskan untuk medirikan pemukiman yang kemudian menjadi Desa 
Tanjung. Sejak tahun 1940-an masyarakat dari Desa Alai berdatangan ke Desa Tanjung.

Pendapatan masyarakat Desa Tanjung ditopang oleh sektor sagu dan

karet. Penghasil sagu berada di dusun satu dan dua yang merupakan suku Melayu dan umumnya berada di tanah aluvial (tanah liat- menurut masyarakat lokal), sedangkan penghasil karet umumnya berasal dari suku Jawa berada di dusun tiga dan dusun empat. Meskipun di dusun empat sudah bercampur Melayu dan Jawa karena perkawinan. Penduduk Desa Tanjung yang tersebar di 4 dusun yaitu Dusun Lalang sebanyak 310 jiwa, dusun Lalang Suir 231 jiwa, Dusun Tanah Merah 266 jiwa dan Dusun Tanah Merah Barat 281 jiwa. Masyarakat bergantung pada pendapatan upah menebang pohon sagu, memotong karet dan bekerja di perusahaan pengolahan sagu. Ada dua pabrik sagu di Desa Tanjung sebagai tempat bagi masyarakat menjual batang sagu dengan harga Rp. 35.000 sampai Rp. 45.000 pertual. Untuk satu batang sagu bisa memperoleh 8-12 tual, jika dirata-ratakan satu pohon sagu petani bisa mendapatkan Rp. 495.000. Sedangkan harga karet Rp. 6.000/kg, harga ini sangat murah jika dibandingakn harga pada tahun 20052010 mencapai Rp. 10.000 sampai Rp. 12.000/kg.

\section{Desa Pulau Burung}

Pulau Burung merupakan desa industri. Kehadiran PT. RSUP (Riau State United Plantation) anak perusahaan Sambu Group di tahun 1985 yang memproduksi kelapa dan nanas. Kehadiran PT RSUP menjadikan Desa Pulau Burung berubah 350 derjat lebih wajah desa kecil yang sekarang menjadi di Rukun Tetangga III menjadi kota dengan luasnya menjadi $14.006 \mathrm{Ha}$ jumlah penduduk 11.238 jiwa dari 2.700 rumah tangga. Menurut data BPS Kecamatan Pulau Burung Dalam Angka 2019, jumlah penduduk Desa Pulau Burung yaitu 11.238 jiw dari $2.700 \mathrm{KK}$, laki laki 5.990 jiwa, perempuan 5.248 jiwa terdiri 7 dusun, $16 \mathrm{RW}$ dan $44 \mathrm{RT}$.

Desa Pulau Burung mengandalkan kanal-kanal sebagai jalur transportasi baik untuk mengangkut manusia maupun barang, terdiri dari 
kanal besar sebagai transportasi utama, kanal tersier yang di wilayah perusahaan setiap 50 hektar terdapat satu kanal, kanal dan kanal cabang tengah yang saling terkoneksi. Di tepi sungai dan muara dari kanal tersebut ditemukan vegetasi seperti pohon nipah dan pohon bakau.Kehadiran kanal yang banyak dan besar-besar ini berpengaruh terhadap subsidensi gambut dan masuknya air asin ke darat, seehingga terjadi kekeringan di musim kemarau dan terjadi banjir ketika air pasang.

Desa Pulau Burung menerima imigrasi tenaga kerja dari seluruh pelosok di Indonesia sebab PT RSUP memerlukan lebih dari 5.000 tenaga kerja.Diperkirakan dari 11.238 jika penduduk di Pulau Burung lebih dari 70 persen merupakan pendatang yang terdiri dari pekerja PT RSUP dan transmigrasi. Sisanya adalah penduduk lokal yang sudah ada sebelum perusahaan datang yang terdiri dari suku Melayu, Bugis, Banjar dan Jawa. Pemerintah mendukung PT RSUP melalui PT Sambu Grup di tahun 1990 melaksanakan program transmigrasi untuk menjadi plasma dari PT Guntung Hasrat Makmur (GHS) dan PT Riau Sakti Transmandiri (RSTM) yang mengembangkan perkebunan kelapa hibrida pola PIR-TRANS di lahan gambut seluas 64.300 ha.Selama periode 1991 hingga 1998 ditempatkan transmigrasi di 28 UPT dengan total 12,016 KK atau 46,964 jiwa. Setiap rumah tangga diberi lahan 2 hektar hingga 3,02 hektar. Dukungan pemerintah tersebut dituang dalam Instruksi Presiden No. 1/1986, Sambu Group diberi tanggung jawab sebagai perkebunan inti atau perusahaan inti untuk mendukung implementasi dan bertindak sebagai perpanjangan pemerintah dalam mengelola Perkebunan-Transmigrasi Perkebunan Inti Rakyat (PIR-Trans).Melalui skema PIR-Trans ini, transmigran diberi rumah dan petak tanah untuk pertanian subsisten dan pertanian (kelapa).Transmigran ini sendiri tidak semuanya berada Kecamatan Pulau Burung. Petani mandiri dan transmigrasi memasok 80 persen kebutuhan kelapa pada PT RSUP.

Industrialisasi belum bisa diakses oleh semua warga Pulau Burung, terutama warga asli lokal yang memiliki keterbatasan pendidikan dan keterampilan. Sementra transmigran yang menjadi plasma dari PT. RSTM 
dan PT. GHS mengalami masalah yang rumit, di satu sisi faktor produksi (pupuk, distibusi) tinggi di sisi lain harga kelapa yang ditetapkan oleh perusahaan masih rendah sehingga tidak seimbang antara faktor produksi dengan harga jual. Selain itu, petani plasma juga mengalami kekurangan modal, dan kurangnya pembinaan dan sosialisasi penerapan teknologi yang tepat.

\section{Desa Dayun}

Desa Dayun merupakan ibu kota Kecamatan Dayun berada di jalan lintas dari Pekanbaru ke Pelabuhan Buton. Dayun berkembang menjadi desa yang inklusif di mana berbagai suku bangsa hidup berdampingan secara harmonis dan damai. Kecamatan Dayun dalam Angka tahun 2017 mencatat luas Desa Dayun 123.500hekar , ${ }^{3}$ dari luas tersebut 350 Ha merupakan tanah mineral, $4000 \mathrm{Ha}$ tanah pemukiman, $123.150 \mathrm{Ha}$ merupakan ekosistem gambut dengan jumlah penduduk yang juga besar mencapai 6.805 jiwa. Selain masyarakat dan lahan pertanian masyarakat di Desa Dayun juga terdapat perusahaan yang berbasis penggunaan lahan yang sangat luas yaitu PT Bumi Siak Pusako (BSP) perusahaan minyak milik Provinsi Riau, April Grup, APP Grup, Perusahaan Sawit PT. Berlian Inti Mekar (BIM) yang merupakan Mahkota Grup dan perkebunan sawit Pemkap Siak. Di sepanjang pinggiran jalan di Desa Dayun terdapat pipa minyak miliki PT BSP yang mengaliri minyak dari Desa Dayun hingga ke Dumai tempat tangki pengapalan dan juga beroperasi Taman Nasional Suaka Marga Zamrud untuk biodiversity hewan dan tumbuhan.

Kampung Dayun sebelumnya hampir seluas Kecamatan Dayun sekarang dan hanya dihuni oleh penduduk asli Dayun yang jumlahnya sangat terbatas. Dipimpin oleh Antan yang dijabat secara turun temurun, sejak berdirinya kampung terdapat 12 Antan. Menurut Kepala Desa Dayun, Nasya

\footnotetext{
${ }^{3}$ Berdasarkan laporan Wikipedia tahun 2016 luas Pekanbaru 446.500 hektar, berdasar data dikeluarkan oleh desa Dayun luas Desa Dayun mencapai 132.000 Ha dengan luas pemukiman mencapai 4000 Ha. (https://id.wikipedia.org/wiki/Kota_Pekanbaru, diunduh 1 Maret 2020, jam 20.00wib)
} 
Nugrik, penduduk asli Dayun berasal dari Talang Mamak yang disebutnya dengan Melayu pedalaman ${ }^{4}$. Thoyib tokoh masyarkaat Dayun secara jelas menyebutkan mereka berasal dari Minangkabau mayoritas bersuku Piliang.

\section{Desa Lalang}

Desa Lalang berdiri tahun 1976 berada dipinggiran laut tepatnya di Selat Malaka, kira-kira 3 sampai 4 kilo meter dari laut merupakan tanah mineral dengan luas keseluruhan 8.157 hektar dengan komposisi tanah mineral 3137 ha, luas gambut 5927 ha. Di Desa Lalang hampir 80 persen merupakan ekosistem gambut, masyarakat memilih tanah mineral sebagai tempat utama aktivitas kehidupan mereka. Masyarakat masuk ke ekosistem gambut karena tanah mineralnya habis terpakai. Di ekosistem gambut masyarakat Desa Lalang hanya menanam komuditas karet, sawit dan nanas. Karet merupakan komoditas utama dengan luas mencapai 265 hektar, diikuti sawit133 hetar, nanas 10 ha, pinang 9 hektar,kelapa 5 hektar dan lain-lain jumlahnya kurang dari 1 hektar. ${ }^{5}$ Kelapa sawit berkembang sejak tahun 90-an, namun karena hasilnya kurang memuaskan masyarakat menggantinya dengan nanas.

Penduduk Desa Lalang terdiri dari 98 persen Melayu, dua persen merupakan dari Minang ( 3 orang) dan tiga rumah tangga suku China, dan 28 Akit. Suku Melayu sendiri berasal dari suku bangsa Bugis, Kampar, Ujung Batu dan Siak. Desa Lalang dibuka oleh suku bangsa China namun sekarang sudah banyak pindah ke daerah lain hanya tinggal tiga rumah tangga. Orang Bugis dan Melayu sudah bercampur dengan melakukan kawin silang,

\footnotetext{
${ }^{4}$ Nasya Nugrik kepala desa Dayun membagi tiga kategori melayu yaitu melayu pesisir, melayu daraan dan melayu pedalaman. Suku Talang Mamak yang ke Dayun dibawah dua kerajaan yaitu kerajaan Pelawan dan kerajaan Siak. Diwawancara tgl 12 Februari di kantor Desa Dayun

${ }^{5}$ Selain karet dan sawit, perhitungan hektar tersebut bukanlah gambaran hamparan sebagai layanya kebun tetapi dicatat berdsararkan tutupan batang pohon yang ada di setiap rumah wargaWawancara dengan Daroni Kepala Desa Lalang, tgl 18 Februari 2020di desa Lalang justru menariknya hampir semua hamparan kawasan desa ditutup pohon durian tetapi tidak masuk sebagai katagori tanaman perkebunan oleh pemerintah Desa Lalang.
} 
sehingga Bugis yang dulunya mendominasi Desa Lalang sudah kalah banyak dengan suku Melayu.

\section{Kearifan Lokal Usaha Tani Masyarakat}

Berdasarkan latar belakang budaya tanah mineral dan tanah aluvial maka kearifan pada kajian ini dibagi menjadi dua level, pertama, level kearifan lokal dasar, yaitu pengetahuai lokal yang berupa nilai-nilai sosial ekonomi, lungkungan dan budaya yang dibawa dari desa asal tetapi tetap turun temurun di tempat baru. Kearifan lokal dasar ini merupakan kearifan yang dipraktekan di tanah meneral seperti menanam karet, praktek pelindungan hutan, dan lain sebagainya. Kearifan dasar ini dibawa dari asal masyarakat dalam hal ini dari sepanjang sungai Kampar, dan dari muara sungai atau daerah lain, seperti orang Kampar, orang Jawa dan Melayu tentu saja nilai tersebut sudah beradaptasi terhadap lokal ekologis;

Kedua, keafian lokal praktis, yaitu pengetuan lokal yang berbasis pada pengetahuan lokal dasar dimodifikasi atau disesesuian dengan kondisi lingkungan kawasan gambut. Contahnya cara menanam karet di kawasan gambut berbeda dengan menanam karet di kawasan tanah mineral. Pengetahuan ini dipengaruhi oleh norma dasar dan kondisi ekologis yang tersedia. Pilihan masyarakat untuk memilih jenis komoditas yang ditanamkan di ekosistem gambut bersumber dari pengetahuannya dasar terdahulu baik dari budaya asalnya maupun menduplikasi di tempat lain, tetapi tentang cara menanamnya mernggunakan pengetahun baru yang menyesuaikan dengan kondisi gambut. .

Temuan di desa-desa yang diteliti merujuk kepada jenis komoditas yang sama, yaitu karet, kelapa, dan pinang. Di Desa Pulau Muda komoditas tanaman awal adalah kelapa, karet, dan pinang kemudian berkembang ke tanaman muda yaitu jagung sebagai andalan utama. Setelah era sawit berkembang, menanam sawit dan tanaman mudanya juga bertambah yaitu sayur-sayuran, cabe, nanas, dan termasuk buah naga. Hal serupa juga dijumpai di Desa Tanjung, Desa Lalang, Desa Dayun dan Desa Pulau 
Burung. Nanas menjadi tamanan sangat populer di semua desa. Dapat disimpulkan bahwa jenis komoditas yang di tanam di ekosistem gambut merupakan komoditas yang biasa hidup di ekosistem tanah mineral, dan nanas merupakan jenis komoditas yang lebih spesifik di eksosistem gambut di lima desa tersebut. Karet, kelapa, dan pinang menjadi pilihan masyarakat untuk ditanam di ekosistem gambut karena merupakan jenis tanaman yang telah terbentuk ekosistemnya. Tersedia bibit, memungkinkan untuk ditanam di gambut dangkal dan telah tersedia di pasar desa. Sedangkan sagu merupakan komoditas yang hidup di tanah aluvial ${ }^{6}$ di pinggir pantai.

Di semua desa tersebut tersedia institusi toke sebagai penjamin kelangsungan konsumsi dan pembeli hasil panen dari komoditas karet, kelapa dan pinang. Masing-masing komoditas memiliki toke berbeda dengan pola yang berbeda pula. Institusi toke ini tidak hanya ada di desa gambut tetapi juga ada di desa-desa lain yang berbasis nelayan, dan tanah mineral di sepanjang Sungai Kampar, Siak, Indragiri dan sungai-sungai lain yang ada di Sumatera, Kalimantan, dan Sulawesi (Amady, 2014: 83-119). Penjelasan di atas menggambarkan bahwa kearifan lokal di desa gambut baru berlaku pada level teknis untuk mengelola ekosistem gambut, belum mencakup semua nilai sosial budaya dalam bermasyarakat.

Kearifan lokal di desa-desa penelitian yang bersifat praktis atau teknis merujuk kepada pilihan adaptasi masyarakat untuk dapat bertahan hidup. Pilihan bertahan hidup merujuk kepada jaminan konsumsi harian dan konsumsi massal. Pilihan pengetahuan lokal bahkan kearifan lokal terfokus kepada pola usaha tani dan sumber - sumber pendapatan lain di kawasan gambut berdasarkan sumber daya dan akses yang dipunyai oleh masyarakat. Kearifan lokal pola usaha tani sudah diteliti oleh Noor (2013: 170-184) yang memaparkan bahwa ada dua kearifan lokal pengelolaan lahan gambut, yaitu pertama, pemenfataan lahan yang terdiri dari(1) sistem mata pencaharian, (2)

\footnotetext{
${ }^{6}$ Tanah aluvial ini merupakan jenis tanah yang terjadi karena endapan lumpur yang biasanya terbawa aliran sungai. Biasanya tanah ini ditemukan dibagian hilir atau daerah rendah (Kompas, 4 Januari 2020)
} 
sistem pemilihan tempat usaha bertani, dan (3) pola usaha tani dan komoditas pilihan yang dipengaruhi oleh persepsi individual atau kelompok dalam menyikapi kondisi lahan dan lingkungannya; dan kedua, kearifan lokal pengelolaan lahan dan air meliputi(1) sistem penyiapan lahan dan pengolahan tanah, (2) penataan lahan, (3) pengelolaan kesuburan tanah, dan (4) sistem pengelolaan air yang dipengaruhi oleh komoditas tanaman yang dikembangkan dan persepsi individual atau kelompok dalam menyikapi kondisi lahan dan lingkungannya. Pada tulisan ini saya sederhanakan menjadi empat yang merupakan rangkain dari dua kearifan lokal yang disampaikan Noor menyesuaikan dengan kondisi desa-desa penelitian.

Pada penelitian ini konsep dari Noor tersebut dioperasionalkan kearifan lokal hanya merujuk kepada pemanfaatan lahan gambut, yaitu 1) mata pencaharian, 2) pemilihan tempat bertani, 3) pilihan komoditas, 4) pengelolaan kesuburan dan tata kelola air. Pemilihan empat konsep ini dengan alasan kondisi di lima desa yang merupakan desa gambut di mana aktivitas pertaniannya sangat terbatas, komuditi dan pola usaha juga terbatas.

\section{Mata Pecaharian}

Mata pencaharian masyarakat desa gambut $^{7}$ terbagi menjadi dua, pertama, mata pencaharian untuk pemenuhan jangka panjang. Jenis mata pencaharian ini meliputi aktivitas pertanian dan pekebunan karet, pinang dan kelapa. Dua komoditas ini merupakan investasi jangka panjang karena baik karet maupun kelapa bisa bertahan hingga 30 tahun, selain itu ada juga tanaman pinang yang biasanya menjadi pembatas. Di Desa Tanjung menanam sagu, meskipun di Desa Pulau Muda dan di Desa Lalang masyarakat beranggapan sagu tidak cocok di tanam di ekosistem gambut, memang dijumpai sagu tumbuhnya di tanah aluvial pinggir sungai, sebagaimana di Desa Tanjung dan Desa Pulau Burung. Bersamaan dengan perkembangan komoditas sawit, sawit menjadi pilihan seperti di Desa Pulau

\footnotetext{
${ }^{7}$ Pola mata pencaharian sepeprti ini juga dijumpai di desa-desa berbasis tanah mineral.
} 
Muda, dan Desa Dayun. Di Desa Lalang, Sawit ditanam tapi masyarakat beranggapan kurang cocok di tanam di tanah ekosistem gambut dengan teknologi yang terbatas, hal serupa juga berlaku di Tanjung dan Pulau Burung di mana masyarakat tidak menanam sawit karena terknologi yang terbatas ekosistemnya belum ada.

Tanaman keras ini selain sebagai jaminan konsumsi bulanan, juga menjadi jaminan komsumsi massal yaitu ketika anggota rumah tangga sakit, anak sekolah, pesta perkawinan, kelahiran bahkan pergi haji. Tanaman keras beserta lahannya menjadi jaminan peminjaman atau istilah di Desa Tanjung di sebut pajak untuk memenuhi kebutuhan massal tadi. Sudah menjadi budaya pada masyarakat desa bukan hanya di desa gambut, menjual lahan untuk memenuhi kebutuhan massa secara mendesak. Setiap membuka hutan baik mineral dan aluvial maupun gambut setiap tahun dijual ketika memenuhi kebutuhan massal.Namun sekarang hutang tidak tersedia, tanah perkebunan juga terbatas yang terjadi hanya menjual lahan dengan mengalihkan ke usaha non tanah seperti di Pulau Muda membuka rumah walet dan ushaa madu kelulut di Lalang.

Di Desa Pulau Muda yang setiap rumah tangganya memiliki rata - rata 4 hektar per rumah tangga banyak dijumpai lahan tidur karena kebijakan melarang membakar. Selain itu, di Pulau Muda bagi yang mempunyai tanah luas, tanah tersebut dijual kepada pendatang untuk membangun rumah walet sebagai mata pencaharian jangka panjang baru di Pulau Muda. Di Dayun, Lalang, Tanjung dan Pulau Burung perkembangan rumah walet tidak banyak tetapi hanya dimiliki oleh suku bangsa China karena rumah walet memerlukan modal cepat yang besar, di mana setiap rumah walet membutuhkan dana Rp.80.000.000,- sampai Rp.100.000.000. Di Desa Lalang berkembang usaha non lahan yaitu peternakan madu kelulut.

Kedua, kebutuhan harian, mingguan dan bulanan. Mata pencaharian untuk memenuhi kebutuhan harian, mingguan dan bulanan merupakan mata pencaharian alternatif untuk memenuhi kebutuhan setiap hari seperti menderes getah karet, menangkap ikan, mencari sayur-sayuran, mecari kayu 
bakar dan buah-buahan di hutan, berbalak menebang pohon, berburu kijang dan hewan lainnya di hutan. Di temui di seluruh desa penelitian bahwa masyarakat memanfaatkan perkarangan atau di lahan khusus untuk menanam berbagai tanaman keras seperti buah-buahan, tanaman muda seperti sayursayur-sayuran, cabe, kangkung, nenas, jenis tanaman palawija dan umbi umbian untuk memenuhi kebutuhan harian, mingguan dan bulanan.

Panjangnya masa panen karet, sagu, dan kelapa menyebabkan masyarakat juga melakukan kegiatan lain untuk memenuhi konsumsi harian. Di Pulau Muda sebelum adanya larangan pembakaran masyarakat menanam jagung sebagai penghasilan bulanan termasuk menjadi nelayan. Di Desa Tanjung di jumpai usaha madu hutan dan madu kelulut serta durian sebagai penghasilan tahunan yang digunakan untuk konsumsi harian. Di Dayun berkembang usaha berkebun di perkarang terutama dilakukan oleh pendatang, begitu juga diDesa Tanjung dimana perkarang dipenuhi tanaman keras dan tanaman muda lainnya.Perkembangan yang menarik dijumpai seluruh desa adalah berkembangnya usaha warung sarapan dan kedai nasi oleh penduduk asli terutama Desa Pulau Muda, Dayun dan Tanjung.Perkembangan ini diasumsikan sebagai pengaruh pendatang dan semakin berkurangnya sumber daya hutan di desa. Di Desa Tanjung dijumpai mata pencaharian baru yang berhubungan industri HTI yaitu menjual biji dari buah akasia dengan harga mencapai Rp.300.000,- perkilo.

Di lahan gambut terutama di kanal-kanal perusahaan masyarakat menangkap ikan, seperti di Pulau Muda masyarakat menggunakan motor bermesin robin untuk menangkap ikan dengan jaring, memancing, memasang lukah, dan empang jenis ikan yang ditangkap ikan tua, bulan bulan, tomang, gabus, dan bujuk, pemanfaatan kanal perusahan untuk menangkap ikan juga dijumpai di Desa Pulau Burung.

\section{Pemilihan Tempat Bertani}

Pemilihan tempat bertani di desa-desa penelitian bermula dari tanah aluvial di pinggir sungai. Kemudian masyarakat mengembangkan lahan 
pertanian ekosistem gambut dengan berdasarkan kemampuan bibit tanaman yang bisa bertahan hidup. Gambut paling dalam yang bisa ditanam oleh masyarakat adalah dengan kedalaman 1 meter, lebih dalam dari itu bibit yang ditanam tidak akan tumbuh dengan baik.

Untuk mengenali kedalaman gambut masyarakat biasanya menggunakan tongkat untuk dicolokan hingga sampai ke tanah di bawah gambut. Jika menemui kedalaman gambut lebih dari 1 meter maka lahan tersebut ditinggalkan tidak jadi sebagai tempat bertani. Selain dengan cara mencolokkan tongkat di atas, masyarakat melihat jenis tanaman yang tumbuh di atasnya yaitu purun tikus (eleocharis dulcis) yang menunjukkan kondisi sangat asam dan kondisi tumpahan air (water logging); pohon galam (meleleucaleucadendron) yang menunjukkan kondisi masam $\mathrm{pH}<3$, drainase berlebih, dan tanah matang; karamunting (melastoma malabatricum) dan bunga merah jambu (rhododendron singapura) menunjukkan tanah yang miskin. Selain itu, masyarakat juga memperhatikan turun naiknya air di kawasan tersebut, daun tanaman berwarna kuning dan bisa dilihat dari bekas air yang tertinggal di pohon tersebut.

Pemilihan tempat bertani saat ini tidak lagi diperlukan, karena masyarakat tidak bisa lagi membuka lahan baru, lahan yang tersedia di masyarakat sekarang adalah lahan-lahan yang telah dibuka sebelumnya dan telah pernah ditanami atau lahan tidur. Fokus masyarakat sekarang adalah pemilihan komoditas yang tepat dan sesuai dengan ekologi politik yang berkembang sekarang ini, terutama memenuhi persyaratan tidak membakar.

\section{Pilihan Komoditas}

Pada bagian sebelumnya sudah disampaikan bahwa penentuan pilihan jenis tananam bukan berdasarkan pengetahuan tentang pengelolaan gambut berkelanjutan. Pemilihan tanaman berdasarkan pada nilai-nilai dasar yang dibawa dari tempat asal. Pilihan ini sangat terlihat di desa-desa penelitian berdasarkan basis suku bangsa. Suku Jawa memilih tanaman karet dan kelapa hal ini dijumpai di Pulau Muda, di Dayun, di Tanjung, Lalang dan Pulau 
Burung. Sedangkan suku Melayu memilih sagu dan bakau. Di Desa Pulau Burung dijumpai petani asal Banjar dan Bugis memilih kelapa dan padi. Di Desa Dayun suku bangsa Nias, dan Jawa asal Sumatera Utara memilih menanam nanas, melon, cabe, semangka di tanah kosong dan di sela sawit.Perkebunan nanas merupakan tanaman yang dijumpai di seluruh desa penelitian dan semua suku bangsa yang ada di desa-desa

\section{Pengelolaan Kesuburan dan Tata Kelola Air}

Membakar bagi masyarakat di desa gambut bukan hanya sebagai cara untuk menyiapkan lahan agar bisa ditanam, membakar merupakan persyaratan untuk mendapat kesuburan tanah dengan hasil yang maksimal. Setiap membuka lahan untuk pertanian selalu dilalui dua tahap pembakaran yaitu membakar besar secara sekaligus seluruh lahan yang sudah ditebang, kemudian dilanjutkan dengan memerun yaitu membakar ulang sisa-sisa pembakaran sebelumnya di tempat-tempat yang ditujukan untuk menanam. Pembakaran merupakan model penyiapan lahan untuk mendapatkan tanah yang subur. Di Desa Tanjung masyarakat melakukan upaya tanam bawang tanpa bakar tetapi merugi karena hasilnya lebih kecil dari biaya produksi. Sementara di Pulau Muda dan di Lalang masyarakat menanam nanas sebab hasil sangat menguntungkan.

Kesuburan tanah sangat ditentukan oleh pengaturan air agar tetap tetap terjadi pembasahan kalau lahan sangat kering juga kurang bagus untuk tanaman. Untuk menyiasati air yang berlebih dan kekurangan air di saat kemarau masyarakat membuat parit (kanal) berukuran lebar 1 meter kedalaman 1 meter di sekeliling lahan yang akan di tanam, kemudian parit keliling tersebut dihubungakan oleh parit-parit kecil di dalamnya.

Masyarakat Pulau Muda membuat kanal (parit) besar dengan lebar satu meter kedalaman satu meter mengelilingi area perkebunan karet dan kelapa, lalu antara kanal dihubungi kanal kecil lebar $40 \mathrm{~cm}$ kedalaman $50 \mathrm{~cm}$, yang berperan untuk menahan laju air dan mengeringkan lapisan gambut agar bisa ditanam karet, kelapa dan pinang serta tanaman lainnya. Masyarakat 
Pulau Muda menanam karet sama polanya dengan kelapa yaitu membuat lubang terlebih dahulu, kemudian tanah gambutnya di padatkan. Setelah itu dimasukan bibit karet ke dalam lubang lalu dipadatkan lagi dengan di injak menggunakan kaki. Tujuan pemadatan tanah gambut agar tanaman bisa tumbuh karena tanah gambut semakin lama sifatnya akan semakin turun kebawah.

Sementara di Desa Lalang, masyarakat juga membuat kanal sebagai mana di Pulau Muda, hanya kanal atau parit ini berfungsi sebagai pengatur air juga untuk proses pembakaran lahan agar api tidak menyebar dan sekaligus sebagai mekanisme pemupukan. Kanal berfungsi juga sebagai pembatas dengan lahan milik orang lain, alat tranportasi memindahkan getah karet dan buah kelapa. Hal yang sama juga ditemukan di Dayun, di Tajung, dan Pulau Burung. Semua desa melakukan tebas bakar terhadap lahan pertanian, baik untuk berladang maupun tanaman muda.

Tanaman keras khususnya kelapa, karet dan sagu untuk menanamnya gambut digali sampai ke tanah di bawah gambut, jika gambut tersebut tidak ada air maka bibit langsung ditanam dan ditambahi pupuk alami, jika masih ada air maka bibit dimasukan dalam polibek atau sabut kelapa seperti yang terjadi Pulau Burung. Kantong plastic ukuran 10 kilo gram yang dibolongbolongi atau sabut kelapa diisi tanah, dimasukan ke dalam lobang lalu dipadatkan.Pola ini dijumpai di semua desa dengan ciri-ciri khusus masingmasing desa.

Untuk menanam tanaman muda, petani membuat petakan-petakan kecil dengan ukuran 100X 100 meter, lalu lalu dikeliling parit kecil dengan lebar $50 \mathrm{~cm}$ dan kedalaman $50 \mathrm{~cm}$, lalu dibuat dundungan (gundukan) hingga $40 \mathrm{~cm}$ diantara gundukan bisa secara langsung berfungsi sebagai aliran untuk mengalir air ke parit keliling sehingga dundungan tetap kering namun tetap mengandung air karena ketersediaan air terjadi. Pada pengelolaannya masyarakat menggunakan teknologi sederhana seperti tajak. Bibit kemudian ditanam di atas gundukan tersebut. Pemupukan baik dengan pupuk alami maupun kimia dilakukan di atas gundukan tadi. Hal terpenting untuk 
memastikan pemanfaatana lahan dan kesuburan lahan adalah tidak mengelola gambut lebih dari satu meter. Meskipun faktor ini disebabkan kareterbatasan dana dan teknologi.

\section{Institusi Toke}

Toke merupakan institusi sosial-ekonomi di desa yang mengatur proses produksi, distribusi dan konsumsi, di mana aktivitas ekonomi di desa berpusat pada toke. Proses produksi, distribusi dan konsumsi sangat tergantung pada toke. Toke adalah institusi ekonomi desa yang menjalankan perniagaan yang bertindak sebagai pedagang, pengumpul dan kreditor. Sebagai pedagang toke menjual kebutuhan harian kepada masyarakat desa secara hutang; sebagai pengumpul toke membeli hasil pertanian untuk dijual ke pasar; dan sebagai kreditor toke meminjamkan uang kepada warga desa. Toke juga sebagai penjamin kelangsungan konsumsi rumah tangga petani menjelang tanaman keras berproduksi.

Toke tidak sama dengan rentenir dan tengkulak, toke dalam proses hutang tidak mengenal jaminan, bunga dan periode jatuh tempo. Rentenir dan tengkulak meminjamkan uang memerlukan jaminan, bunga dan jatuh tempo hutang, seperti musim panen. Padi yang akan panen, pemiliknya dipinjamkan uang, uang dibayar dengan hasil panen padi dengan harga yan ditetapkan sepihak oleh rentenir atau tengkulak tadi. Sementara toke merupakan institusi sosial ekonomi yang menjamin kelangsungan konsumsi petani/nelayan yang tidak bisa bekerja karena kondisi alam, misalnya musim gelombang laut tinggi dan musim penghujan, produsksi dan distribusi hasil pertanian warga. Ketika toke tidak mampu memenuhi keperluan konsumsi dan membeli getah warga pada saat bersamaan hutang dianggap lunas.

Toke ini tidak hanya ditemui di kawasan gambut, tetapi seluruh desadesa di Sumatera, Kalimantan, dan daerah lain dengan nama yang berbedabeda. Di seluruh desa penelitian dikenal istilah toke meskipun fungsinya tidak selalu sama. Di Tanjung, Di Lalang, Di Dayun dan di Pulau Murung fungsi toke sudah mendekati dengan fungsi tengkulak, sebagai tempat peminjam 
uang tetapi tidak melaksanakan fungsi jaminan sosial. Di Pulau muda masih ditemukan toke yang fungsinya masih hampir sama yaitu menjual kebutuhan konsumsi harian masyarakat, membeli hasil pertanian masyarakat, meminjamkan uang dan sudah harus pakai jaminan.

\section{PENUTUP}

Studi ini menyampaikan temuan bahwa nilai dasar pada masyarakat desa gambut adalah budaya tanah mineral dan budaya tanah aluvial. Di desa yang diteliti menunjukkan bahwa awal kehadiran kearifan lokal di desa gambut adalah pertama, budaya tanah mineral yang dibawa dari hulu sungai Kampar, Jawa, dan daerah tanah mineral lainnya dengan tanaman utama karet, kelapa, dan pinang; kedua, budaya tanah aluvial yang berbasis maritim dengan mata pencaharian sebagai nelayan, budidaya sagu dan menjual pohon bakau. Di antara dua budaya tersebut terdapat gabungan dua budaya yaitu budaya tanah mineral dan budaya maritim berbasis tanah aluvial dengan tanaman sagu, karet dan pinang secara bersamaan. Di Desa Tanjung Tebing Tinggi Barat Kepulauan Meranti, kedua budaya tersebut hadir mengikuti budayanya masing-masing, di mana Melayu dengan tanaman sagu dan budaya darat dari Jawa dengan menanam karet dan kedua suku bangsa tersebut menanam pinang dan kelapa.

Desa Pulau Muda memulai dengan menanam padi di Pulau Muda yang terletak tengah sungai yang merupakan tanah alluvial, masyarakat berpindah ke ekosistem gambut karena kenaikan tinggi air. Begitu juga di Desa Tanjung, masyarakat mengelola ekosistem gambut setelah tanah aluvial dipinggir sungai sudah tidak tersedia lagi. Bahkan Desa Pulau Burung yang bisa dikatakan semua gambut, awal kedatangan juga di tanah aluvial untuk tanam sagu di hutan bakau. Hal serupa juga terjadi di Desa Lalang, mulai dari tanah mineral setelah tanah mineral habis masyarakat masuk ke ekosistem gambut. Sementara Desa Dayun mayoritas masih di tanah mineral sedangkan ekosistem gambut dikelola perusahaan dan pendatang yang baru masuk ke Desa Dayun. 
Ide tentang teknologi pengolahan lahan gambut dengan membakar dan budi daya anaman diperkirakan berasal dari budaya tanah mineral. Di desa desa gambut dijumpai tanaman yang dipilih adalah tanaman keras yang hidup tanah mineral yaitu karet, pinang, dan kelapa, termasuk sagu yang berasal dari tanah mineral dan aluvial. Pola penanamannya di ekosistem gambut, adalah gambut dangkal paling dalam 1 meter, dan di tanam di tanah mineral di bawah gambut. Itulah sebabnya pemikiran tentang keberlanjutan eksositem gambut belum berkembang di masyarakat. Di semua desa penelitian belum ditemukan ada ide keberlanjutan ekosistem gambut dari masyarakat. Ide-ide yang muncul adalah keinginan pemanfaatan teknologi pengolahan gambut untuk mempermudah aktivitas pertanian. Selama ini masyarakat membiarkan gambut dalam tidak dikelola bukan karena ide keberlanjutan melainkan terbatasnya pengetahuan dan teknologi untuk mengola gambut dalam tersebut.

Secara umum hasil penelitian ini dapat disimpulkan berikut pertama, masyarakat yang hidup di kawasan gambut membangun komunitasnya berbasis ekonomi sebagai upaya ekstensifikasi lahan dari komoditas pertanian.Komunitas dibangun tidak berbasis gambut tetapi bebasis tanah mineral dan tanah aluvial perisir pantai laut atau sungai.

Kedua, pengetahuan masyarakat tentang gambut bersifat pratikal, masih terbatas pada pemanfaatan gambut untuk sumber daya ekonomi, ketahanan sosial dan sarana transportasi. Fungsi-fungsi keberlanjutan, keberagaman, oksigen dan keselamatan bumi baru dikenal oleh masyarakat setelah tahun 2010 hingga sekarang karena terjadinya kabut asap, informasi media sosial dan gerakan sosial yang dilakukan para aktivitis.

Masyarakat di desa gambut menjaga gambut secara natural di mana mereka berladang secara terbatas dan tidak melakukan kanalisasi yang dalam sehingga tidak terjadi pengeringan air dibawah gambut.Kerusakan gambut sekarang dipicu oleh pemanfaatan ekosistem gambut skala besar oleh koprorasi dengan membangun kanal yang dalam sehingga terjadi pengeringan dan subsidensi serta banjir pada musim penghujan. 


\section{DAFTAR PUSTAKA}

Amady, M.Rawa El, 2014. Tauke dan Budaya Hutang: Perubahan Budaya Pada Masyarakat Desa.Yogyakarta:AG Litera dan Padi Institut

Amady, M.Rawa El, 2015. "Pengelolaan Gambut Berbasis Kerafian Lokal (sebuah rangkuman)" dalam, Oktavian, Harry, dkk, 2015.Pengelolaan Gambu Berbasis Kearifan Lokal, Pekanbaru:Scale Up

Noor, Muhammad 2013." Kearifan Lokal dalam Pengelolaan Lahan Gambut", dalam Prosiding Seminar Nasional Pengelolaan Lahan Gambut Berkelanjutan, 2012. Jakarta. Badan Penelitian dan Pengembangan Pertanian Kementerian Pertanian

Noor YR, Heyde J. 2007. Pengelolaan Lahan Gambut Berbasis Masyarakat di Indonesia. Proyek Climate Change, Forest and Peatland in Indonesia. Bogor (ID): Wetland International-Indonesia Programme dan Wildlife Habitat.

Noor, M., Mukhlis dan Achmadi. 2007."Pengelolaan Sumberdaya Lahan Rawa Dalam Perspektif Pengembangan Inovasi Pertanian". Dalam D. Subardja et all. (ed) Kearifan Lokal; Peranian di lahan Rawa, Buku III. 14- 15 September 2006. Bogor, BBSDLP

Prasetijo, Adi, 2008. "Adaptasi dalam Anropologi”, diunduh dari https://etnobudaya.net/2008/01/28/adaptasi-dalam-anthropologi pada 24 Desember 2019 pukul 21.00 Wib.

Prayitno, U. S. 2013. Kontektualisasi Kearifan Lokal Dalam Pemberdayaan Masyarakat, Jakarta. Pusat Pengkajian, Pengolahan Data dan Informasi (P3DI) Setjen DPR Republik Indonesia dan Azza Grafika

Seger, Sugiyanto, 2019. "Kearifan Lokal Petani dan Kelestariam Gambut (Studi Kasus : Desa Lukun Kecamatan Tebing TInggi Timur".Jurnal JOM FISIP Vol. 6: Edisi I Januari - Juni 2019. Hal 1-15

Utomo, Bambang Budi, 2015. Kehidupan Purba di Lahan Gambut. Surakarta: PT. Aksara Sinerji Media

Vita, 2016.“Adaptasi Masyarakat Pra-Sriwijaya di Lahan Basah Situs Air Sigihan Sumatera Selatan” dalam Kalpataru, Majalah Arkeologi Vol. 25 No. 1, Mei 2016 Hal 1-14 


\section{Daftar Informan}

1.Amir, 43 tahun, Peani Desa Pulau Muda Kecamatan Teluk Meranti

2.Doroni, 40 tahun, kepala Desa Lalang

3.Nusya Nurgi, 29 tahun Kepala Desa Dayun

4.Thoyib, 85 tahun, tokoh Masyarakat Dayun. 